\title{
FAKTOR-FAKTOR YANG MEMPENGARUHI PEDICULOSIS CAPITIS PADA ANAK-ANAK UMUR 6-12 TAHUN DI PONDOK PESANTREN SIROJAN MUSTAQIM DAN PENDUDUK RW O3 KELURAHAN PONDOK RANGGON KECAMATAN CIPAYUNG JAKARTA TIMUR
}

\author{
Catu Umirestu Nurdiani ${ }^{1)}$ \\ ${ }^{1}$ Program Studi Analis Kesehatan, Fakultas Kesehatan, Universitas Mohammad Husni Thamrin \\ Correspondence author: Catu Umirestu Nurdiani, ctani_enan@yahoo.com, Jakarta, Indonesia
}

\begin{abstract}
ABSTRAK
Pedikulosis capitis dikategorikan sebagai penyakit yang terabaikan tetapi masih menjadi masalah kesehatan. Pediculus humanus capitis dengan mudah ditularkan melalui hubungan langsung antar individu atau benda pribadi yang digunakan bersama. Pedikulosis capitis memiliki berbagai faktor risiko yang dapat meningkatkan terjadinya infestasi Pediculus humanus capitis. Penyakit ini menyerang semua usia terutama usia muda dan cepat meluas dalam lingkungan hidup yang padat seperti asrama dan panti asuhan. Gejala klinis yang khas berupa gatal disertai adanya bekas garukan. Penelitian ini untuk Mengetahui angka pedikulosis capitis pada anak-anak umur 6-12 tahun di Pondok Pesantren Sirojan Mustaqim dan lingkungan penduduk rw 03 di Kelurahan Pondok Ranggon Kecamatan Cipayung Jakarta Timur. Penelitian ini menggunakan metode cross sectional dengan metode total populasi pada asrama 55 sedangkan pada penduduk disesuaikan dengan jumlah sampel di asrama. Pada ketentuan yang didapatkan hasil positif sebesar $71(64,54 \%), 41$ sampel $(57,7 \%)$ di asrama dan 30 sampel (42,3\%) dipenduduk, dari hasil uji chi-square didapatkan hubungan bermakna pada kondisi rambut dengan angka pedikulosis capitis $(\mathrm{P}=0,05)$, adanya hubungan antara kondisi rambut, tidak adanya hubungan antara perilaku anak, adanya hubungan antara tempat tinggal, adanya hubungan antara jenis kelamin, dan tidak ada hubungan antara keadaan kulit kepala. Hasil penelitian dapat disimpulkan bahwa angka pedikulosis kapitis kepada responden untuk selalu menjaga kebersihan tempat tinggal dan perilaku kebersihan rambut serta menghindari pemakaian alat-alat pribadi secara bergantian atau bersama-sama seperti sisir, bantal dan kerudung.
\end{abstract}

Kata kunci : Pediculus humanus capitis, pedikulosi kapitis,personal hygine

\begin{abstract}
Pediculosis capitis is categorized as a neglected disease but is still a health problem. Pediculus humanus capitis is easily transmitted through direct contact between individuals or shared personal objects. Pediculosis capitis has various risk factors that can increase the incidence of Pediculus humanus capitis infestation. This disease attacks all ages, especially young people and quickly spreads in a dense living environment such as dormitories and orphanages. Typical clinical symptoms include itching accompanied by scratching marks. This study was to determine the number of pediculosis capitis in children aged 6-12 years at the Sirojan Mustaqim Islamic Boarding School and the neighborhood residents of rw 03 in Pondok Ranggon Village, Cipayung District, East JakartaThis study used a cross sectional method with a total population method of 55 dormitories, while the population was adjusted to the number of samples in the dormitory. In terms of obtained positive results of $71(64.54 \%)$, 41 samples $(57.7 \%)$ in the dormitory and 30 samples $(42.3 \%)$ were populated, the chi-square test results showed a significant relationship in hair condition with the number pediculosis capitis $(\mathrm{P}=0.05)$, there was a relationship between hair conditions, there was no relationship between children's behavior, there was a relationship between residence, there was a relationship between sexes, and there was no relationship between the condition of the scalp. The results of the study concluded that the number of pediculosis capitis for respondents was to always maintain the cleanliness of the residence and hair hygiene behavior and avoid using personal tools alternately or together such as combs, pillows and headscarves.
\end{abstract}

Keywords: Pediculus humanus capitis, pediculus capitis, personal hygine

Open Journal System (OJS): journal.thamrin.ac.id

http://journal.thamrin.ac.id/index.php/anakes/issue/view/35 


\section{PENDAHULUAN}

Pedikulosis capitis kejadiannya cukup tinggi di Indonesia, khususnya dibagian pulau jawa kutu ini disebut Tuma. Tetapi, di Indonesia sampai saat ini belum ada angka pasti mengenai terjadinya pedikulosis capitis (Rahman, 2014). Hal ini disebabkan karena banyak penderita yang mengobati sendiri dan tidak melapor ke petugas kesehatan maka disimpulkan bahwa Pediculosis capitis telah menjadi endemik di seluruh dunia baik negara maju maupun negara berkembang dan baik dinegara beriklim tropis maupun iklim sedang (Akib, Sabilu \& Fachlevy, 2016 ).

Pedikulosis capitis ini merupakan salah satu masalah kesehatan pada anak sekolah terutama pada tingkat pra sekolah, sekolah dasar, dan sekolah menengah pertama (Sari \& Fatriyadi, 2016). Kutu kepala pedikulosis capitis merupakan parasit yang muncul di kepala manusia. Ukuran tubuh organisme ini sangat kecil, sehingga secara sekilas sulit terlihat oleh mata. Kutu kepala tergolong serangga yang hidup di selasela rambut dan menempel pada kulit kepala. Hewan yang berukuran sangat kecil ini mempertahankan hidupnya dengan cara menghisap darah melalui kulit kepala, dan berkembang biak dengan cara bertelur dan menyarangkan telurnya pada helai-helai rambut, terutama pada pangkal rambut. Dampak kutu kepala terhadap kesehatan adalah dapat menyebabkan koreng pada kepala, penyakit pediculosis capatis, dan akan mengganggu waktu istirahat serta mengurangi konsentrasi dan kurang percaya diri. Dan pada anak anak dapat menyebabkan anemia. Anemia membuat anak-anak menjadi lesu, dan mempengaruhi kinerja belajar dan fungsi kognitif (Alatas, 2013)

Pedikulosis capitis merupakan infestasi Pediculus humanus capitis atau kutu kulit kepala manusia yang bersifat menetap dan dapat menimbulkan berbagai masalah (Alatas, 2013). Pedikulosis capitis sebenarnya perlu mendapat perhatian karena penyakit ini sering menyerang anak-anak. Rasa gatal yang hebat mengganggu ketenangan tidur dan mengganggu konsentrasi belajar anak (Hadidjaja, 2011).

Meskipun hanya dapat ditularkan melalui kontak langsung, berbagai penelitian sebelumnya menunjukkan beberapa faktor risiko berupa karakteristik dan kebiasaan dari responden yang memicu peningkatan dari kejadian pedikulosis capitis. Prevalensi pedikulosis kapitis pada anak sekolah lebih tinggi dibanding pada orang dewasa. Responden berjenis kelamin perempuan lebih banyak terserang dibanding anak laki-laki, karena biasanya rambut perempuan lebih panjang (Rassami dan Soonwera, 2012:903).

Penelitian ini dilakukan pada anak-anak umur 6-12 tahun di Pondok Pesantren Sirojan Mustaqim dan penduduk warga Rw 03 Kelurahan Pondok Ranggon Kecamatan Cipayung Jakarta Timur. Pondok Pesantren Sirojan Mustaqim adalah sebuah yayasan yang terletak di kawasan pemukiman padat penduduk di Kelurahan Pondok Ranggon Kecamatan Cipayung Jakarta Timur. Setiap harinya, mereka tinggal dan belajar di lingkungan yang sama. Di pondok pesantren ini setiap anak tidur dan beraktifitas bersama. Mereka tidur dalam ruangan berukuran $8 \times 7$ meter dengan jumlah anak tiap kamar sebanyak 18 orang. 
Karena intensitas perempuan dan kontak yang sering inilah maka dapat timbul kebiasaan individu untuk saling meminjam barang-barang pribadi seperti sisir, bantal, kerudung, handuk dan lain-lain. Karakteristik rambut baik berdasarkan jenis dan panjang rambut juga menjadi faktor yang perlu diperhatikan terhadap adanya pedikulosis capitis. Penyakit menular yang dipengaruhi oleh lingkungan dan perilaku seperti penyakit kulit masih menjadi masalag kesehatan masyarakat yang dominan di lingkungan padat penghuni sepertipondok pesantren (Badari, 2007). Salah satu penyakit kulit yang sering ditemukan di pondok pesantren adalah pedikulosis capitis (infestasi kutu kepala) yang disebabkan oleh Pediculus humanus capitis (kutu kepala) (Bugayong,2011). Berdasarkan penelitian yang dilakukan Riswandi pada tahun 1996, prevalensi santri yang mengalami pedikulosis capitis di dua buah pesantren khusus untuk santri perempuan di Jakarta sebesar 40,2\% dan 47,5\% sedangkan penelitian Restiana pada tahun 2010 menunjukkan bahwa sebesar $71,3 \%$ santri disebuah pondok pesantren di Yogyakarta terinfestasi kutu kepala (Alatas, 2013)

Penduduk warga Rw 03 Kelurahan Pondok Ranggon Kecamatan Cipayung Jakarta Timur. Kondisi anakanak di lingkungan yang kurang menjaga kebersihan diri dan padatnya pemukiman penduduk menjadi faktor yang perlu di perhatikan terhadap adanya pedikulosis capitis. Masyarakat yang cenderung berperilaku acuh tak acuh dan kurang perhatian terhadap pemeliharaan kesehatan pribadi masing masing mencerminkan kurangnya pengetahuan masyarakat tersebut terhadap persepsi sakit dan pengetahuan tentang penyebab dan gejala sakit. Kebiasaan tidak sehat seperti memakai benda pribadi secara bergantian, jika tidak ada pihak yang mengingatkan maka perilaku tidak sehat tersebut akan terus dilakukan dalam kehidupan sehari-hari (Ramdan, 2013). Perilaku perawatan diri individu mempertahankan kesehatannya, oleh karena itu perilaku kesehatan menjadi aspek yang penting menjaga kesehatan individu karena perilaku yang baik akan meminimalkan masuknya mikroorganisme yang ada di mana-mana dan pada akhirnya mencegah seseorang terkena penyakit baik penyakit kulit, penyakit infeksi, penyakit mulut, dan penyakit saluran cerna atau bahhkan dapat menghilangkan fungsi bagian tubuh tertentu, seperti halnya infeksi pediculosis capitis pada rambut kepala (Laily, 2012).

Berdasarkan uraian diatas, maka penelitian ini dianggap perlu dilakukan. Peneltian ini berjudul " Faktorfaktor yang mempengaruhi Pedikulosis capitis pada anak-anak umur 6-12 tahun di Pondok Pesantren Sirojan Mustaqim dan Penduduk Rw 03 Kelurahan Pondok Ranggon Kecamatan Cipayung Jakarta Timur.

\section{METODE}

Populasi pada penelitian ini adalah anak-anak umur 6-12 tahun dihitung dengan rumus cross sectional dengan hasil sebanyak 55 anak yang tinggal di Pondok Pesantren Sirojan Mustaqim dan 55 anak penduduk yang tinggal bersama keluarga di Penduduk rw 03 Kelurahan Pondok Ranggon Kecamatan Cipayung Jakarta Timur. Sampelnya dari anak-anak yang tinggal di Penduduk rw 03 adalah 55 anak Sedangkan pada pendudukdisesuai dengan jumlah sampel di Pondok Pesantren. Dalam penelitian ini data 
yang dikumpulkan merupakan data primer, yaitu pemeriksaan pediculus humanus capitis pada anak-anak umur 6-12 tahun di Pondok Pesantren Sirojan Mustaqim dan penduduk rw 03 di Kelurahan Pondok Ranggon Kecamatan Cipayung Jakarta Timur. Observasi dengan pemeriksaan spesimen adalah hasil sisiran dari responden yaitu anak pada anak-anak Pondok Pesantren Sirojan Mustaqim dan Pondok Pesantren Sirojan Mustaqim dan Penduduk rw 03 Kelurahan Pondok Ranggon Kecamatan Cipayung Jakarta Timur. Wawancara dilakukan terhadap responden untuk mengetahui karakteristik responden, keadaan rambut dan perilaku responden. Wawancara dilakukan dengan menggunakan instrumen quesioner.

\section{HASIL \& PEMBAHASAN}

Jumlah seluruh sampel dalam penelitian ini adalah 110 orang anak yang terdiri dari 55 anak di Pondok Pesantren Sirojan Mustaqim dan 55 anak di penduduk rw 03 di Kelurahan Pondok Ranggon Kecamatan Cipayung Jakarta Timur. Hasil menunjukan bahwa yang positif Pediculus humanus capitis sebanyak 71 sampel $(64,54 \%)$ yang terdiri dari 41 sampel $(57,7 \%)$ dari 55 sampel di Pondok Pesantren Sirojan Mustaqim dan 30 sampel (42,3\%) dari 55 sampel di peduduk rw 03 di Kelurahan Pondok Kecamatan Cipayung Jakarta Timur. Spesies yang ditemukan seluruhnya adalah Pediculus humanus capitis.

Tabel 2

Angka infestasi Pediculus humanus capitis pada Anak-Anak Umur 6-12 Tahun di Pondok Pesantren Sirojan Mustaqim dan Penduduk RW 03 di Kelurahan Pondok Ranggon Kecamatan Cipayung Jakarta Timur

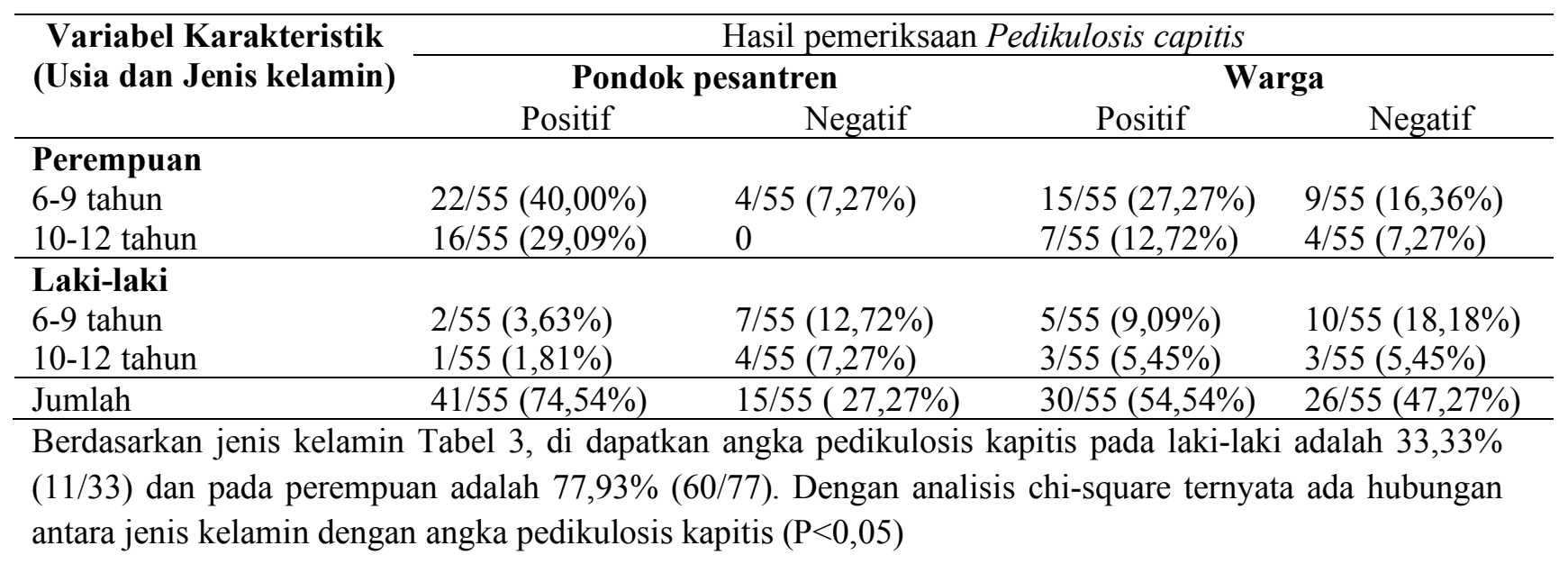

Tabel 3

Hubungan antara Jenis Kelamin dengan Pedikulosis capitis pada Anak-Anak Umur 6-12 Tahun di Pondok Pesantren Sirojan Mustaqim dan Penduduk RW 03 di Kelurahan Pondok Ranggon Kecamatan Cipayung Jakarta Timur. Jenis Hasil pemeriksaan P-value 


\begin{tabular}{|c|c|c|c|c|}
\hline kelamin & Positif & Negatif & Jumlah & \\
\hline Perempuan & $60(77,93 \%)$ & $17(22,07 \%)$ & $77(100 \%)$ & 0,01 \\
\hline Laki-laki & $11(33.33 \%)$ & $22(66,67 \%)$ & $33(100 \%)$ & \\
\hline Total & $71(64,54 \%)$ & $39(35,45 \%)$ & $110(100 \%)$ & \\
\hline
\end{tabular}

Stadium yang di temukan di tiap penderita jumlahnya cukup beragam, yaitu stadium telur, nimfa dan dewasa.Gambar setiap stadium dapat dilihat pada Gambar :

Angka Pedikulosis capitis dan hubungannya berdasarkan kondisi rambut yaitu jenis rambut dan panjang rambut dapat dilihat pada Tabel 4 Terlihat bahwa angka pedikulosis capitis pada anak jenis rambut lurus adalah $73,2 \%(52 / 80)$ rambut ikal adalah $22,5 \%$ (16/19) dan jenis rambut keriting adalah 4,2\% (3/11). Dengan analisis Chi-square ternyata ada hubungan antara jenis rambut dengan besarnya angka Pedikulosis kapitis $(\mathrm{P}<0,05)$.

Tabel 4

Hubungan antara Kondisi rambut dengan Pedikulosis capitis pada Anak-Anak Umur 6-12 Tahun di Pondok Pesantren Sirojan Mustaqim dan Penduduk rw 03 di Kelurahan Pondok Ranggon Kecamatan Cipayung Jakarta Timur.

\begin{tabular}{|c|c|c|c|c|}
\hline \multirow{2}{*}{$\begin{array}{c}\text { Kondisi rambut } \\
\text { (Menurut jenis } \\
\text { rambut) }\end{array}$} & \multicolumn{3}{|c|}{ Hasil pemeriksaan } & \multirow{2}{*}{ P-value } \\
\hline & Positif & Negatif & Jumlah & \\
\hline Lurus & $52(73,2 \%)$ & $28(71,8 \%)$ & $80(100 \%)$ & \multirow{3}{*}{0,05} \\
\hline Ikal & $16(22,5 \%)$ & $3(7,7 \%)$ & $19(100 \%)$ & \\
\hline Keriting & $3(4,2 \%)$ & $8(20,5 \%)$ & $11(100 \%)$ & \\
\hline Total & $71(64,54 \%)$ & $39(35,45 \%)$ & $110(100 \%)$ & \\
\hline \multicolumn{5}{|l|}{$\begin{array}{c}\text { (menurut Panjang } \\
\text { rambut) }\end{array}$} \\
\hline$\leq 20 \mathrm{~cm}$ & $20(28,2 \%)$ & $33(34,6 \%)$ & $53(48,2 \%)$ & \multirow{3}{*}{0,05} \\
\hline$\geq 20 \mathrm{~cm}$ & $51(71,8 \%)$ & $6(15,4 \%)$ & $57(51,8 \%)$ & \\
\hline Total & $71(64,54 \%)$ & $39(35,45 \%)$ & $110(100 \%)$ & \\
\hline
\end{tabular}

Berdasarkan panjang rambut, didapatkan angka pedikulosis kapitis pada anak-anak dengan panjang rambut $\leq 20 \mathrm{~cm}$ adalah $28,2 \%$ (20/53) dan pada panjang rambut $\geq 20 \mathrm{~cm}$ adalah 71,8\% (51/57) Dengan analisis Chi-square ternyata ada hubungan antara panjang rambut dengan pedikulosis kapitis $(\mathrm{P}<0,05)$

Angka pedikulosis kapitis dan hubungannya berdasarkan keadaan kulit kepala dapat dilihat pada Table 5. Terlihat bahwa angka pedikulosis kapitis pada anak dengan rambut berminyak adalah 17 orang $(68,0 \%)$ dan pada rambut tidak berminyak adalah 54 orang $(63,5 \%)$ Dengan uji chi-square ternyata tidak ada hubungan antara keadaan kulit kepala dengan angka pedikulosis kapitis $(\mathrm{P}>0,05)$

\section{Tabel 5}


Hubungan antara Keadaan kulit rambut dengan Pediculosis capitis pada Anak-Anak Umur 6-12 Tahun di Pondok Pesantren Sirojan Mustaqim dan Penduduk RW 03 di Kelurahan Pondok Ranggon Kecamatan Cipayung Jakarta Timur.

\begin{tabular}{ccccc}
\hline Keadaan kepala & \multicolumn{3}{c}{ Hasil Pemeriksaan } & \multirow{2}{*}{ P-value } \\
\cline { 2 - 4 } & Positif & Negatif & Jumlah & \\
\hline Berminyak & $17(68,0 \%)$ & $8(32,0 \%)$ & $25(100 \%)$ & \multirow{2}{*}{0,86} \\
\cline { 1 - 4 } $\begin{array}{c}\text { Tidak } \\
\text { Berminyak }\end{array}$ & $54(63,5 \%)$ & $31(36,5 \%)$ & $85(100 \%)$ & \\
\hline Total & $71(64,54 \%)$ & $39(35,45 \%)$ & $110(100 \%)$ & \\
\hline
\end{tabular}

Agka pedikulosis kapitis dan hubungannya berdasarkan tempat tinggal dapat dilihat pada Table 6. Terlihat bahwa angka pedikulosis kapitis pada anak yang tinggal di pondok pesantren Sirojan Mustaqim sebanyak $57,71 \%$ (41/55) dan pada anak yang tinggal bersama keluarga sebanyak 42,3\% (30/55). Dengan uji chisquare ternyata di dapatkan hubungan yang bermakna antara kondisi tempat tinggal dengan angka pedikulosis capitis $(\mathrm{P}<0,04)$.

Tabel 6

Hubungan antara Tempat tinggal dengan Pedikulosis capitis pada Anak-Anak Umur 6-12 Tahun di Pondok Pesantren Sirojan Mustaqim dan Penduduk RW 03 di Kelurahan Pondok Ranggon Kecamatan Cipayung Jakarta Timur.

\begin{tabular}{ccccc}
\hline Tempat tinggal & \multicolumn{3}{c}{ Hasil pemeriksaan } & \multirow{2}{*}{ P-value } \\
\cline { 2 - 4 } & Positif & Negatif & Jumlah & \\
\hline Asrama & $41(57,7 \%)$ & $14(35,9 \%)$ & $55(100 \%)$ & \multirow{2}{*}{0,04} \\
\hline Warga & $30(42,3 \%)$ & $25(64,1 \%)$ & $55(100 \%)$ & \\
\hline Total & $71(64,54 \%)$ & $39(34,45 \%)$ & $110(100 \%)$ & \\
\hline
\end{tabular}

Pada perempuan yang melakukan cuci rambut $<1$ kali seminggu yang positif sebanyak 52 orang $(73,2 \%)$, 1 kali seminggu yang positif sebanyak 4 orang $(5,6 \%)$ dan $>1$ kali lebih dari seminggu yang positif sebanyak $15(21,1 \%)$ dapat dilihat pada Tabel 7. Ternyata dengan uji statistik Chi-square, frekuensi mencuci rambut kepala tidak memiliki hubungan dengan Pediculus humanus capitis $(\mathrm{P}<0,05)$.

Dalam hal pemakaian shampo jumlah yang pada kategori selalu memakai yang positif sebanyak 68 orang $(95,8 \%)$, pada kategori jarang memakai sebanyak $3(4,2 \%)$ dan tidak pernah memakai shampo (0\%) dapat dilihat pada Tabel 7. Ternyata dengan uji statistik Chi-square, pemakaian shampo tidak memiliki hubungan dengan Pediculus humanus capitis $(\mathrm{P}<0,05)$.

Tabel 7

Hubungan antara Frekuensi cuci rambut dengan Pedikulosis capitis pada Anak-Anak Umur 6-12 Tahun di Pondok Pesantren Sirojan Mustaqim dan Penduduk RW 03 di Kelurahan Pondok Ranggon Kecamatan Cipayung Jakarta Timur.

\begin{tabular}{ccccc}
\hline Frekuensi & \multicolumn{3}{c}{ Hasil pemeriksaan } & P-value \\
\cline { 2 - 3 } mencuci rambut & Positif & Negatif & Jumlah & \\
\hline$<1$ kali seminggu & $52(73,2 \%)$ & $26(66,7 \%)$ & 0,11 \\
\hline 1 kali seminggu & $4(5,6 \%)$ & $7(17,9 \%)$ & \\
\hline$>1$ kali lebih dari & $15(21,1 \%)$ & $6(15,4 \%)$ & \\
\hline
\end{tabular}




\begin{tabular}{ccccc}
\hline seminggu & & & \\
\cline { 1 - 4 } Total & $71(64,54 \%)$ & $39(34,45 \%)$ & $110(100 \%)$ & \\
\cline { 1 - 4 } Menggunakan shampo & & & & \\
\cline { 1 - 4 } Selalu & $68(95,8 \%)$ & $35(89,7 \%)$ & $103(93,6 \%)$ & \\
Jarang & $3(4,2 \%)$ & $4(10,3 \%)$ & $7(6,4 \%)$ & \\
\hline Tidak pernah & $0(0 \%)$ & $0(0 \%)$ & $(0 \%)$ & \\
\hline Total & $71(64,54 \%)$ & $39(34,45 \%)$ & $110(100 \%)$ & \\
\hline
\end{tabular}

Dari hasil penelitian diketahui pada perempuan dengan kebiasaan pinjam meminjam sisir kategori todak pernah yang positif sebanyak 34 orang (47,9\%), kategori kadang yang positif sebanyak 30 orang (42,3\%) dan kategori sering yang positif sebanyak 7 orang $(9,9 \%)$ dapat dilihat pada Tabel 8 . Ternyata dengan uji statistik Chi-square, kebiasaan pinjam meminjam sisir tidak memiliki hubungan dengan Pediculus humanus capitis $(\mathrm{P}<0,05)$.

Dari hasil penelitian diketahui bahwa pada perempuan dengan kebiasaan tidur bersama menggunakan bantal yang positif sebanyak 41 orang $(57,7 \%)$, kategori kadang yang positif sebanyak 21 orang $(29,6 \%)$ dan kategori sering yang positif sebanyak 9 orang $(12,7 \%)$ dapat dilihat pada Tabel 8 . Ternyata dengan uji statistik Chi-square, kebiasaan menggunakan bantal bersamaan tidak memiliki hubungan dengan Pediculus humanus capitis $(\mathrm{P}>0,05)$.

Dari hasil penelitian diketahui bahwa pada perempuan dengan kebiasaan pinjam meminjam kerudung/topi yang positif sebanyak 36 orang (50,7\%), kategori kadang yang positif sebanyak 24 orang $(33,8 \%)$ dan kategori sering yang positif sebanyak 11 orang $(15,5 \%)$ dapat dilihat pada Tabel 8 . Ternyata dengan uji statistik Chi-square, kebiasaan pinjam meminjam kerudung/mukena tidak memiliki hubungan dengan Pediculus humanus capitis $(\mathrm{P}>0,05)$.

Table 8

Hubungan antara Pinjam meminjam sisir dengan Pedikulosis capitis pada Anak-Anak Umur 6-12 Tahun di Pondok Pesantren Sirojan Mustaqim dan Penduduk RW 03 di Kelurahan Pondok Ranggon Kecamatan Cipayung Jakarta Timur.

\begin{tabular}{|c|c|c|c|c|}
\hline \multirow{2}{*}{$\begin{array}{l}\text { Kebiasaan pinjam } \\
\text { meminjam sisir }\end{array}$} & \multicolumn{3}{|c|}{ Hasil pemeriksaan } & \multirow[t]{2}{*}{ P-value } \\
\hline & Positif & Negatif & Jumlah & \\
\hline Tidak pernah & $34(47,9 \%)$ & $14(35,9 \%)$ & $48(100 \%)$ & \multirow[t]{4}{*}{0,41} \\
\hline Kadang & $30(42,3 \%)$ & $21(53,8 \%)$ & $51(100 \%)$ & \\
\hline Sering & $7(9,9 \%)$ & $4(10,3 \%)$ & $11(100 \%)$ & \\
\hline Total & $71(64,54 \%)$ & $39(34,45 \%)$ & $110(100 \%)$ & \\
\hline \multicolumn{5}{|l|}{ Meminjam bantal } \\
\hline Tidak pernah & $41(57,7 \%)$ & $14(35,9 \%)$ & $55(100 \%)$ & \multirow[t]{4}{*}{0,08} \\
\hline Kadang & $21(29,6 \%)$ & $18(46,2 \%)$ & $39(100 \%)$ & \\
\hline Sering & $9(12,7 \%)$ & $7(17,9 \%)$ & $16(100 \%)$ & \\
\hline Total & $71(64,54 \%)$ & $39(34,45 \%)$ & $110(100 \%)$ & \\
\hline \multicolumn{5}{|c|}{$\begin{array}{c}\text { Kebiasaan pinjam } \\
\text { meminjam kerudung/topi }\end{array}$} \\
\hline Tidak pernah & $36(50,7 \%)$ & $20(51,3 \%)$ & $56(100 \%)$ & 0,99 \\
\hline
\end{tabular}

Open Journal System (OJS): journal.thamrin.ac.id 


\begin{tabular}{lccc}
\hline Kadang & $24(33,8 \%)$ & $13(33,3 \%)$ & $37(100 \%)$ \\
\hline Sering & $11(15,5 \%)$ & $6(15,4 \%)$ & $17(100 \%)$ \\
\hline Total & $71(64,54 \%)$ & $39(34,45 \%)$ & $110(100 \%)$ \\
\hline
\end{tabular}

Berdasarkan penelitian yang telah dilakukan terhadap 110 orang anak yang terdiri dari dua tempat yaitu 55 anak di Pondok pesantren Sirojan Mustaqim dan 55 anak penduduk di rw 03 kelurahan Pondok Ranggon Kecamatan Cipayung di dapat hasil anak 71 (64,54\%) menderita pedikulosis capitis. Dibandingkan dengan hasil penelitian Zeni (2017) yang sampel nya 31 anak yang besarnya 41,9\% angka pedikulosis kapitis pada penelitian ini lebih tinggi. Perbedaan tersebut bisa disebabkan dari jumlah sampel yang diperiksa dan tempat tinggal sampel. Menurut ( Herlina, 2013), pedikulosis capitis cepat meluas di lingkungan hidup yang padat. Hal ini dikarenakan lingkungan yang padat, menjadi intensitas pertemuan yang sering, diantara anak-anak di lingkungan ini. Sehingga menimbulkan kebiasaan untuk saling meminjam barang pribadi saat anak-anak bermain bersama.

Berdasarkan jenis kelamin, ternyata ada hubungan antara jenis kelamin dengan angka pedikulosis capitis $(\mathrm{P}<0,05)$. Hasil penelitian sejalan dengan penelitian yang dilaksanakan oleh (Zulinda et al., 2017) yang menyebutkan bahwa siswa perempuan lebih banyak menderita pedikulosis kapitis di banding laki-laki dengan pravelensi $77,1 \%$ untuk perempuan dan 8,1 untuk laki-laki dan nilai $\mathrm{P}=0,00$. Hal ini disebabkan karena umumnya perempuan berambut lebih panjang dari pada laki-laki, sehingga membutuhkan perawatan yang baik. Rambut yang kotor, lembab, jarang disisir dan dikeramas merupakan tempat yang disukai untuk berkembangbiak kutu rambut kepala Pediculus humanus capitis.

Berdasarkan jenis rambut ternyata ada hubungan antara jenis rambut dengan angka pedikulosis capitis $(\mathrm{P}<0,05)$. Hal ini dikarenakan kutu kepala menyukai jenis rambut ikal yang cenderung lebih lebat dan tebal dibanding rambut lurus dan keriting. Sehingga nyaman untuk ditinggali dan nyaman untuk meletakkan telurnya.

Berdasarkan panjang rambut ternyata ada hubungan antara panjang rambut dengan angka pedikulosis capitis $(<0,05)$. Menurut penelitian (Esy Maryanti, Suri Dwi Lesmana, 2018) hasil uji statistik chi-square di dapatkan nilai $\mathrm{P}$ value $0,000(\mathrm{P}<0,05)$. Hal ini menunjukan bahwa terdapat hubungan yang signifikan antara panjang rambut dengan infestasi pediculus humanus capitis. Hal ini berhubungan erat dengan cara merawat rambut kepala baik dari segi frekuensi cuci rambut, kebiasaan mengikat rambut, dan memakai kerudung. Penggunaan kerudung (jilbab) mungkin dapat membatasi transmisi pediculus humanus capitis dapat terjadi pada saat bermain di luar jam sekolah. Kondisi rambut dari kulit kepala cenderung menjadi lebih lembab terutama pada anak dengan rambut panjang yang diikat ketika menggunakan kerudung, rambut yang basah setelah keramas juga membuat kondisi rambut menjadi lembab. Kondisi inilah yang disuka oleh Pediculus humanus capitis untuk berkembang sehingga infestasinya dapat meningkat. 
Berdasarkan keadaan kulit kepala ternyata tidak ada hubungan antara keadaan kulit kepala dengan angka pedikulosis capitis $(\mathrm{P}>0,05)$. Hal ini karena berdasarkan penelitian yang telah dilakukan anak yang positif Pediculus humanus capitis tidak selalu memiliki kulit kepala yang berminyak. Faktor-faktor yang mungkin berhubungan juga tidak dapat dijadikan acuan dalam menentukan besarnya persentase pedikulosis kapitis setiap anak.

Berdasarkan tempat tinggal ternyata ada hubungan antara tempat tinggal dengan angka pedikulosis capitis $(\mathrm{P}<0,04)$. hal ini keharusan anak-anak pondok pesantren dimana setiap kamar ditinggali oleh 18 orang anak, dan penularan pedikulosis kapitis mudah terjadi karena kontak antara penderita pedikulosis kapitis dengan yang tidak menderita pedikulosis capitis melalui kontak langsung maupun tidak langsung. Sedangkan pada anak-anak yang tinggal dirumah bersama keluarga adanya intensitas pertemuan atau kontak langsung antara penderita pedikulosis capitis dengan yang tidak menderita pedikulosis kapitis lebih rendah dibanding dengan anak-anak yang diharuskan tinggal bersama di asrama. Keharusan anak-anak pondok pesantren untuk tidur di kamar yang karena kontak antara penderita pedikulosis capitis dengan yang tidak menderita pedikulosis kapitis melalui kontak langsung maupun tidak langsung. Prevalensi pedikulosis capitis pada anak yang tidur sendiri lebih rendah dibanding anak yang tidur bersama-sama dengan orang lain. Hal ini disebabkan pada waktu tidur terjdi kontak langsung antara kepala dan kepala atau dengan peantara bantal, dan alat-alat tidur.

Berdasarkan hasil menggunakan shampo ternyata tidak ada hubungan antara pemakaian shampo dengan angka pedikulosis capitis $(\mathrm{P}>0,05)$. hal ini berdasarkan penelitian yang telah dilakukan anak yang positif pediculosis humanus capitis tidak selalu menggunakan shampo pada saat mencuci rambut. faktor-faktor yang mungkin berhubungan juga tidak dapat dijadikan acuan dalam menentukan besarnya presentase pediculosis capitis setiap anak.

Berdasarkan kebiasaan meminjam barang ( sisir, bantal, kerudung/topi) ternyata tidak ada hubungan antara kebiasaan meminjam barang dengan angka pediculosis capitis $(\mathrm{P}>0,05)$ Hal ini berdasarkan penelitian yang telah dilakukan bahwa anak yang positif pediculus humanus capitis tidak selalu memiliki kebiasaan meminjam barang. faktor-faktor yang mungkin berhubungan juga tidak dapat dijadikan acuan dalam menentukan besarnya presentase pediculosis capitis setiap anak.

\section{SIMPULAN}

Dari hasil penelitian 110 sampel yang diperiksa pada anak-anak umur 6-12 tahun di Pondok Pesantren Sirojan Mustaqim dan penduduk Rw 03 di Kelurahan Pondok Ranggon Kecamatan Cipayung Jakarta Timur dapat diambil kesimpulan sebagai berikut angka pediculosis capitis sebanyak 64,54\% (110/71) dan angka terbanyak mayoritas dari anak-anak di Pondok Pesantren Sirojan Mustaqim lebih banyak yaitu 57,7\% (41/55) dan di penduduk Rw 03 diperoleh hasil 42,3\% (30/55). Adanya hubungan antara kondisi 
rambut dengan pedikulosis capitis pada anak-anak umur 6-12 tahun di Pondok Pesantren Sirojan Mustaqim dan penduduk Rw 03 di Kelurahan Pondok Ranggon Kecamatan Cipayung Jakarta Timur, antara lain : Jenis Rambut dan Panjang Rambut

\section{UCAPAN TERIMA KASIH}

Penulis mengucapkan terima kasihh kepada Prodi D III Analis Kesehatan Universitas MH Thamrin berperan serta dalam penelitian ini.

\section{DAFTAR PUSTAKA}

1. Akib, N., Y. Sabilu, dan A.F. Fachlevy. 2016. Studi Epidemiologi Penyakit Pedikulosis Kapitis Pada Siswa Sekolah Dasar Negeri 08 Moramo Utara Kabupaten Konawe Selatan Tahun 2016. Sulawesi Tenggara: Jimkesmas. (5): 1-1

2. Alatas, S. S. S. (2013). Hubungan Tingkat Pengetahuan Mengenai Pedikulosis Kapitis dengan Karakteristik Demografi Santri Pesantren X, Jakarta Timur. EJournal Kedokteran Indonesia. https://doi.org/10.23886/ejki.1.1596.53-57

3. AlBashtawy, M., \& Hasna, F. (2012). Pediculosis capitis among primary-school children in Mafraq Governorate, Jordan. Eastern Mediterranean health journal, 18(1), 43

4. Bohl B. 2015. Clinical Practice Update: Pediculosis Capitis. Pediatric Nursing, 41(5):227-34.

5. Esy Maryanti, Suri Dwi Lesmana, M. N. (2018). Hubungan Faktor Risiko dengan Infestasi Pediculus humanus capitis pada Anak Panti Asuhan di Kota Pekanbaru.

6. Fadilah, H. 2015. Perbedaan Metode Ceramah dan Leaflet Terhadap Skor Pengetahuan Santriwati Tentang Pediculoiss capitis di Pondok Pesantren Al-Mimbar Sambongdukuh Jombang. Skripsi. Jakarta: UIN Syarif Hidayatullah Jakarta.

7. Frankowski BL, Bocchini JA. Head Lice. 9. Head Lice Infestations:A Clinical Update. Canadian Pediatr Child Health; 2004:9(9):647-50 Offic J of the Am Acad of Pediatr; 2010:126:392-403.

8. Hadidjaja, P. 2011. Dasar Parasitologi Klinik. Edisi I. Jakarta : Fakultas Kedokteran Universitas Indonesia.

9. Hardiyanti, N. I. et al. (2015) 'Penatalaksanaan Pediculosis capitis Treatment of Pediculosis capitis', 4, pp. 47-52.IJD (Indian Journal of Dermatology) [database on the internet]. Treatment of pediculosis capitis.

10. Laily,Sulistyo. 2012. Kebutuhan Dasar Manusia dan Proses Keperawatan. Jakarta: Salemba Medika. Hlm. 52-68.

11. Lesshafft, H., A. Baier, H. Guerra, A. Terashima dan H. Feldmeier. 2013. Prevalence and Risk Factors Associated with Pediculosis Capitis in an Impoverished Urban Community in Lima, Peru. Journal of Global Infectious Diseases. 5(4): 138-144

12. Madke, B. \& Khopkar, U., 2012. Pediculosis capitis : an update. Indian Journal of Dermatology, Venereology, and Leprology, 78, pp.429-37.

13. Meinking TL. C Buckhart. Infestations. In : Jean L. Bolognia, Joseph L. Jorizzo, Ronald P. Rapini editors. Dermatology volume one. Britain : Mosby; 2008; p 1321 - 8

14. Michigan Department Of Education. 2013. Michigan Head Lice Manual. Lansing: Michigan Department Of Community Health.

15. Rahman, Z. A. 2014. Faktor-Faktor yang Berhubungan Dengan Kejadian Pedikulosis kapitis Pada Santri Pesantren Rhodlotul Quran Semarang. Tesis. Semarang: Fakultas Kedokteran Universitas Diponegoro. 